\title{
ANALYSIS OF POLYPHENOLIC COMPOSITION AND STABILITY OF MAGISTRAL PREPARATION BASED ON SALVIAE OFFICINALIS FOLIUM
}

\author{
ADAM KOWALCZYK ${ }^{*}$, MACIEJ WŁODARCZYK', \\ CARLO IGNAZIO GIOVANNI TUBEROSO ${ }^{2}$ and IZABELA FECKA
}

\author{
'Department of Pharmacognosy and Herbal Medicines, Faculty of Pharmacy, \\ Wroclaw Medical University, 211A Borowska St., 50-556 Wrocław, Poland \\ ${ }^{2}$ Department of Life and Environmental Sciences, Unit of Pharmaceutical, \\ Pharmacological and Nutraceutical Sciences, University of Cagliari, \\ 72 Via Ospedale St., I-09124 Cagliari, Italy
}

\begin{abstract}
A magistral preparation based on the sage leaf decoction or infusion is one of the most popular herbal prescriptions prepared in pharmacies in Lower Silesia (Poland) for gargling in the case of pharyngitis or mouth infections. Other components of this preparation are boric acid, aluminum(III) acetotartrate or Burow's solution, and glycerol. The study aimed to investigate the polyphenolic composition and relations between herbal and chemical ingredients that are present in this mixture in comparison with the traditional aqueous galenic forms - infusion and decoction. The analysis was performed using high-performance liquid chromatography with diode-array detector (HPLC-DAD) and electrospray ionization mass spectrometry (ESI-MS) methods. The main polyphenolic ingredients of sage leaf were rosmarinic acid (RA) and luteolin 7-O- $\beta$-glucuronide. The RA predominance was observed in the infusion, decoction and magistral preparation. Comparing the contents of analyzed polyphenols, it was confirmed that their levels in the decoction were higher than in the infusion. Thus, the pharmacological activity of the examined magistral preparation results from the presence of boric acid, aluminum(III) salts and polyphenolic components of sage leaf hot water extract. The succeeding study showed that in the presence of excess salts of aluminum(III) and boric acid, sage polyphenols are partially soluble in an aqueous medium (mainly phenolic acids) and complexed as precipitated sediment (especially flavonoids). The aqueous solutions of this preparation obtained according to the recommendation are cloudy, which suggests limited solubility of the formed complexes. Therefore, the therapeutic activity should be associated with the presence of water-soluble caffeic acid esters like rosmarinic acid. The influence of luteolin glycosides coordination complexes is not evident. The obtained results also confirm the stability of the examined prescription formulation in the conditions of cold storage $\left(4-6^{\circ} \mathrm{C}\right)$ within 7 days from its production.
\end{abstract}

Keywords: Salvia officinalis, magistral preparation, flavonoids, phenolic acids, complexes

The genus Salvia is the largest member of Lamiaceae Lindl. (syn. Labiatae Juss.) family, containing over 900 species throughout the world $(1,2)$. The most common species is Salvia officinalis L. (common sage), which is native to the Mediterranean region $(3,4)$. Salviae officinalis folium (Salviae off. fol., sage leaf) is traditionally used as herbal tea. An infusion from this comminuted herbal substance and its liquid or semi-solid dosage forms are applied for oromucosal or cutaneous use. The herbal medicinal products resulting from sage leaf are recommended for relief of mild dyspeptic complaints such as heartburn and bloating, excessive sweating, inflammations in the mouth or the throat and minor skin inflammations (5). Also, common sage leaves have been shown to have carminative, antispasmodic, antiseptic, and astringent properties (6). Pharmacological activities of sage leaf and their preparations are due to different chemical compounds including polyphenols (phenolic acids about $3.5 \%$, flavonoids about $1.1 \%$ ), triterpenes (ursolic acid up to $3.5 \%$, oleanolic acid up to $0.4 \%$ ), diterpenes (carnosic acid, carnosol, rosmanol) and essential oil (up to $3 \%$, inter alia thujone and 1,8-cineole) (5). However, in the hot water extracts - decoctions or infusions - non-volatile compounds dominate (3).

\footnotetext{
* Corresponding author: e-mail: adam.kowalczyk@umed.wroc.pl
} 
The simplest form of a pharmaceutical formulation to be made from this medicinal plant is a hot aqueous extract from leaves. It is easy to prepare and use in self-treatment by patients as well, which may explain its popularity. One of the most popularly prescribed preparations of Salviae off. fol. (commonly known as the magistral formulas) made in pharmacies in Lower Silesia (Poland) is a mixture based on the sage leaf decoction or infusion with the addition of boric acid, aluminum(III) acetotartrate or Burow's solution, and glycerol. This magistral product is used after dilution in warm water for gargling in pharyngitis or mouth infections.

The aim of this study was to investigate the polyphenolic composition and interactions between herbal and chemical compounds present in the sage leaf magistral preparation made in accordance with the pharmaceutical standards, and compared with the traditional sage aqueous galenic forms. The stability of polyphenolic components in the recommended storage conditions of this preparation was also analyzed.

\section{EXPERIMENTAL}

\section{Materials}

Dried common sage leaves (Salviae off.fol.) were bought in community pharmacies in Wroclaw, Poland, in shredded form as well as herbal tea bags (samples So1-So7). The materials came from two manufacturers - Flos (So1, So2, So3, So5; series: 1101, 1012, 2012, 01012; Mokrsko, Poland) or Kawon (So4, So6, So7; series: 885.2011, 02112011, 01112011; Krajewice, Poland). They had the herbal medicinal product status and differed in series and expiration dates. Boric acid (Acidum boricum) and aluminium acetotartrate (Aluminii acetotartras = Aluminii acetas tartras) (ALTACET) (Sandoz Polska, Warszawa, Poland), as well as glycerol 86\% (Aflofarm, Pabianice, Poland) were for pharmaceutical use.

\section{Chemicals and standards}

All of the organic solvents and reagents used in the analysis of polyphenols were of analytical grade (Chempur, Piekary Śląskie, Poland). Acetonitrile was HPLC gradient grade. Water (Aq) was glassdistilled and deionized. Methanol $(\mathrm{MeOH})$, acetonitrile, and 98-100\% formic acid were obtained from Merck (Darmstadt, Germany). Caffeic acid (CA) and rosmarinic acid (RA) were bought from Fluka (Buchs, Switzerland), luteolin (L) from Roth (Karlsruhe, Germany). Luteolin 7-O- $\beta$-glucuronide (Lgr) was isolated from the wild thyme herb (10, 11). Stock standard solutions $(1 \mathrm{mg} / \mathrm{mL})$ were pre- pared by dissolving an accurate amount of the individual compound in methanol and filtered through a $0.45 \mu \mathrm{m}$ membrane filter (Millipore, Burlington, MA, USA). Working standard solutions (0.02-0.3 $\mathrm{mg} / \mathrm{mL}$ ) were obtained by dilution with $50 \%$ aq. methanol (v/v).

\section{Sage leaf aqueous methanolic extract (Ex50Me)}

$0.25 \mathrm{~g}$ of previously powdered plant material was poured into $50 \mathrm{~mL}$ of $50 \%$ aq. methanol (v/v) and extracted in an ultrasonic bath (Sonorex Digital; Bandelin, Berlin, Germany) for $15 \mathrm{~min}$ at $70 \%$ of nominal power, at a temperature up to $40^{\circ} \mathrm{C}$. The solutions after extraction were filtered through a cotton pad into volumetric flasks $(50 \mathrm{~mL})$ and complemented with $50 \%$ aq. methanol to the prescribed volume. After stirring, $2.5 \mathrm{~mL}$ of the obtained solutions were filtered through $0.45 \mu \mathrm{m}$ membrane filters (Millipore) and analyzed by HPLC-DAD. The drug-to-extract ratio (DER) of Ex50Me was $1: 200$ $(\mathrm{m} / \mathrm{v})$.

\section{Sage leaf infusion (Inf.)}

To obtain infusions, boiling water $(40 \mathrm{~mL})$ was poured over the unshredded sage leaf $(5.0 \mathrm{~g})$, mixed and filtered after $15 \mathrm{~min}$ through a cotton filter into a volumetric flask $(50.0 \mathrm{~mL})$ and complemented with boiling water to the prescribed volume. $1.0 \mathrm{~g}$ of the obtained infusion was moved to a volumetric flask $(10.0 \mathrm{~mL})$ and made up to $10 \mathrm{~mL}$ with water. $2.5 \mathrm{~mL}$ of this solution was filtered through $0.45 \mu \mathrm{m}$ membrane filters (Millipore) and analyzed by HPLC-DAD. The DER of Inf. was $1: 10(\mathrm{~m} / \mathrm{m})$.

\section{Sage leaf decoction (Dec.)}

The unshredded sage leaf $(5.0 \mathrm{~g})$ was transferred to the infuser. Then $40.0 \mathrm{~mL}$ of room-temperature water was added, mixed, covered, and placed in a water bath at a temperature of over $90^{\circ} \mathrm{C}$ for 30 min. After this time, the content of the infuser was filtered through a cotton filter into a volumetric flask $(50.0 \mathrm{~mL})$ and boiling water was added to the prescribed volume. $1.0 \mathrm{~g}$ of the obtained decoction was moved to a volumetric flask $(10.0 \mathrm{~mL})$ and made up to $10 \mathrm{~mL}$ with water. $2.5 \mathrm{~mL}$ of this solution was filtered through $0.45 \mu \mathrm{m}$ membrane filters (Millipore) and examined by HPLC-DAD. The DER of Dec. was $1: 10(\mathrm{~m} / \mathrm{m})$.

\section{Sage leaf magistral preparation (Prep.)}

$5.0 \mathrm{~g}$ of unshredded sage leaf was transferred to the infuser and then $40.0 \mathrm{~mL}$ of water at room temperature was added, mixed, covered, and placed in a water bath at a temperature above $90^{\circ} \mathrm{C}$ for 30 
min. After this time it was removed from the bath, filtered through a cotton filter to a volumetric flask $(50.0 \mathrm{~mL})$ and supplemented with boiling water to $40.0 \mathrm{~g}$. Then $0.5 \mathrm{~g}$ of powdered ALTACET tablet and $0.5 \mathrm{~g}$ of boric acid were added to the decoction and supplemented to $50.0 \mathrm{~g}$ with glycerol thoroughly mixed. $1.0 \mathrm{~g}$ of the obtained magistral preparation was placed into volumetric flasks $(10.0 \mathrm{~mL})$. One sample was supplemented with water and the other with $50 \%$ aq. methanol (v/v). However, there were no significant differences in the chromatographic profile. Consequently, samples for stability testing of the formulation were prepared analogously, but using only water. $2.5 \mathrm{~mL}$ of such solutions were filtered through $0.45 \mu \mathrm{m}$ membrane filters (Millipore) and subjected to HPLC-DAD analysis. The DER of Prep. was $1: 10(\mathrm{~m} / \mathrm{m})$.

\section{HPLC-DAD analysis and quantification}

The polyphenolic compounds were identified using a liquid chromatography system (Smartline; Knauer, Berlin, Germany) equipped with a pump (Manager 5000), dynamic mixing chamber V7119-1, PDA 2800 detector and manual 6-port2-channel injection valve (A1366). Data were processed using EuroChrom 3.05 (V7568-5). The separation was performed on a $250 \times 4.6 \mathrm{~mm}, 5$ $\mu \mathrm{m}, \mathrm{C} 18$ Hypersil GOLD column with a $10 \times 4.6$ $\mathrm{mm}, 5 \mu \mathrm{m}, \mathrm{C} 18$ Hypersil GOLD precolumn (Thermo Fisher Scientific, Waltham, MA, USA). Detection was carried out using a UV/Vis diode detector. The compounds were monitored at 254 , 280, 320 and $360 \mathrm{~nm}$, and UV spectra from 200 to $600 \mathrm{~nm}$ (spectra were scanned at a rate of $8 \mathrm{~nm}$ per second) were recorded for peak characterization. Solvent solutions were vacuum degassed with ultrasonication prior to usage. The composition of mobile phases and gradient profile for HPLC analyses were as follows: solvent $\mathrm{A}-5 \%$ formic acid in acetonitrile; solvent $\mathrm{B}-5 \%$ formic acid in water; commencing with $10 \% \mathrm{~A}$ in $\mathrm{B}$, rising to $40 \% \mathrm{~A}$ in $\mathrm{B}$ after $25 \mathrm{~min}$, then to $70 \% \mathrm{~A}$ in $\mathrm{B}$ after $30 \mathrm{~min}$; then isocratic $70 \% \mathrm{~A}$ in $\mathrm{B}$ up to $50 \mathrm{~min}$. The flow rate was $0.7 \mathrm{~mL} / \mathrm{min}$. The injection volume for all samples was $20 \mu \mathrm{L}$. All chromatographic experiments were performed at $22 \pm 2^{\circ} \mathrm{C}$ (Smartline Column Thermostat, Knauer, Berlin, Germany). The method was fully validated as described earlier $(7,8)$.

Calibration equations for quantified phenolic acids and flavonoids were assessed at 6 concentration levels $(0.02-0.30 \mathrm{mg} / \mathrm{mL}$ or $\mathrm{mg} / \mathrm{g})$, and duplicate injections were performed for each concentration. The linearity of calibration curves was con- firmed by plotting the peak areas $(y, \mathrm{mAU} / \mathrm{s})$ and the corresponding concentration $(x, \mathrm{mg} / \mathrm{mL})$. Limits of detection (LD) and quantitation (LQ) were calculated from calibration equations based on the signal-tonoise ratio $(\mathrm{S} / \mathrm{N}=3: 1$ and $\mathrm{S} / \mathrm{N}=10: 1)$ and expressed as the concentration of the examined compound $(\mathrm{mg} / \mathrm{mL})$.

The content of the analyzed polyphenolic compounds in the sage leaf aq. methanolic extracts, infusions, decoctions, and magistral preparations was determined using an external model based on calibration equations. The mean values $\pm \mathrm{SD}$ of individual compounds, as well as the sum of phenolic acids (SPA; CA + RA), the sum of flavonoids (SF; $\mathrm{Lgr}+\mathrm{L}$ ) and the sum of polyphenols (SPP; CA + $\mathrm{RA}+\mathrm{Lgr}+\mathrm{L}$ ), expressed in milligrams per gram were calculated for each Salviae off. fol. product. Six independent aq. methanolic extracts, infusions, decoctions and magistral preparations from sage products were made.

\section{Sage leaf magistral preparation stability}

Six standard prepared Salviae off. fol. magistral preparations $(45 \mathrm{~mL})$ from a sample of So1 and two preparations for each of the samples So2, So3 and So7 were kept at temperature $4-6^{\circ} \mathrm{C}$ in a refrigerator not longer than seven days after manufacture. The content of polyphenols was analyzed for each preparation three times on the day of preparation $-0,1,2$, 3,4 and 7 days.

Analysis of interactions of sage polyphenols with chemical components of magistral preparation

A model mixture of four standards (Mix4; CA $+\mathrm{RA}+\mathrm{Lgr}+\mathrm{L})$ at a concentration of $0.49-0.64$ $\mathrm{mg} / \mathrm{mL}$ (Table 3) was used in the analysis of interactions between sage leaf magistral preparation components. Mix 4 was added at a ratio of $1: 10$ $(\mathrm{m} / \mathrm{m})$ to aqueous solutions of glycerol (s2; AqGLYCEROL, $49+1, \mathrm{~m} / \mathrm{m})$, boric acid ( 33 ; AqBORIC ACID, $49.5+0.5$, w/w), aluminum (III) acetotartrate ( $\mathrm{s} 4$; Aq-ALTACET, $49.5+0.5, \mathrm{~m} / \mathrm{m}$ ) and their combination (s5; Aq-BORIC ACIDALTACET-GLYCEROL, $40+0.5+0.5+9, \mathrm{~m} / \mathrm{m}$; $\mathrm{pH} \sim 3.9$ ) in proportions matching the prescription composition (described below). As a reference solution (s1), a tenfold dilution of Mix4 was prepared using water-methanol $(1+1, \mathrm{~m} / \mathrm{m})$. The set model mixtures of sage polyphenols with the remaining components of the magistral preparation were evaluated visually and the content of polyphenols was determined by HPLC-DAD. The analysis was carried out in three replications. 
ESI-MS analysis of sage polyphenol complexes

High-resolution mass spectrometry (HRMS) measurements were conducted on the ESI-qTOF Compact mass spectrometer (Bruker Daltonics, Bremen, Germany). The instrument was operated in both positive and negative mode. The calibration was achieved with freshly prepared formate clusters with $\mathrm{m} / \mathrm{z}$ standard deviation below $1 \mathrm{ppm}$ and followed by lock mass specific for the analyzed ligand. The basic parameters were: scan range $80-1300 \mathrm{~m} / \mathrm{z}$, nebulizer pressure 0.4 bar, dry gas $\left(\mathrm{N}_{2}\right) 4.0 \mathrm{~L} / \mathrm{min}$, temperature $180^{\circ} \mathrm{C}$, capillary voltage $4.5 \mathrm{kV}$. The flow speed of direct injection was set to $3 \mu \mathrm{L} / \mathrm{min}$. The samples were dissolved in methanol without ionization enhancers to avoid disruption of formed complexes. Interactions of sage polyphenols were analyzed in binary mixtures of CA, RA, L, Lgr (each at $50 \mu \mathrm{mol}$ ) with boric acid (BA at $100 \mu \mathrm{mol}$ ) or aluminum(III) acetotartrate (Al(III)AcT at $100 \mu \mathrm{mol}$, ALTACET).

All statistical analysis was performed by Microsoft Excel 2016 software using the following methods: Spearman regression, nonparametric analysis of variance (the Kruskal-Wallis test) and the F-test, assuming a level of statistical significance $\mathrm{p}=0.05$.

\section{RESULTS AND DISCUSSION}

In autumn and winter, one of the most frequently used extemporaneous magistral preparation in pharmacies in Lower Silesia (Poland) is a preparation made from the sage leaf (Salviae off. fol.) with the addition of boric acid and aluminum salts, which shows local antimicrobial, anti-fungal, anti-inflammatory, and astringent effects. In the present study, an analysis of the composition and comparison of the content of phenolic acids (CA, RA) and flavonoids (L, Lgr) in hot water extracts (Inf., Dec.) and magistral preparation (Prep.) from Salviae off. fol. made according to the following prescription was carried out.

$R p$.

Dec./Inf. Salviae off. fol.

$20.0 / 160.0$

Acidi borici

Altaceti/Aluminii subacetatis solution

Glycerini

ad 200.0

M.D.S. Mix before use. One tablespoon of the mixture to be diluted in 1/2 a glass of warm water for gargling in the case of pharyngitis or mouth infections 2-3 times a day.

The mentioned formula of sage leaf magistral preparation was not found in the scientific literature in the form that is well known from the Silesian pharmaceutical market. The most similar formula is mentioned in the current specialist literature. In the 19th-20th century and contemporary manuals concerning herbal preparations, several similar prescriptions were found. Different combinations of borax or aluminum salts with sage leaves were noted

Table 1. Linearity parameters of used HPLC-DAD method $(n=6 \times 2)$.

\begin{tabular}{|c|c|c|c|c|c|c|c|c|}
\hline \multirow{2}{*}{ Compound } & \multirow{2}{*}{$\begin{array}{c}\lambda \\
{[\mathrm{nm}]}\end{array}$} & \multirow{2}{*}{$\begin{array}{c}\mathrm{t}_{\mathrm{R}}(\mathrm{SD}) \\
{[\mathrm{min} .]}\end{array}$} & \multirow{2}{*}{$\mathrm{a}$} & \multirow{2}{*}{$\mathrm{b}$} & \multirow{2}{*}{$r$} & \multirow{2}{*}{$\begin{array}{c}\text { Range } \\
{[\mathrm{mg} / \mathrm{mL}]}\end{array}$} & LD & LQ \\
\hline & & & & & & & \multicolumn{2}{|c|}{$[\mu \mathrm{g} / \mathrm{mL}]$} \\
\hline $\mathrm{CA}$ & 320 & $10.86(0.08)$ & 3007.26 & -3.27 & $0.9985^{*}$ & $0.02-0.15$ & 1.00 & 3.33 \\
\hline RA & 320 & $20.24(0.14)$ & 1542.02 & -4.83 & $0.9990 *$ & $0.02-0.20$ & 8.92 & 29.74 \\
\hline Lgr & 360 & $16.81(0.35)$ & 1151.68 & -2.80 & $0.9942 *$ & $0.02-0.30$ & 2.60 & 8.68 \\
\hline $\mathrm{L}$ & 360 & $25.61(0.76)$ & 1958.15 & -7.87 & $0.9979 *$ & $0.02-0.20$ & 1.53 & 5.11 \\
\hline
\end{tabular}

$r$ - regression coefficient;

Standards: CA - Caffeic acid (Fluka), RA - Rosmarinic acid (Fluka), Lgr - Luteolin-7-O- $\beta$-glucuronide (isolated from herb of Thymus serpyllum L.), L - Luteolin (Roth), *F-test, $\mathrm{p}<0.0001$.

Table 2. Average content of analyzed polyphenols in Salviae off. fol. (So1-So7) infusions, decoctions and preparations [mg/g] $(\mathrm{n}=6 \times 3)$.

\begin{tabular}{|c|c|c|c|c|c|c|c|c|}
\hline Compound & Ex50Me & SD & Inf. & SD & Dec. & SD & Prep. & SD \\
\hline CA & 0.60 & 0.25 & $0.40^{*}$ & 0.08 & $0.56^{*}$ & 0.10 & 0.43 & 0.14 \\
\hline RA & $6.22^{*}$ & 2.81 & 4.07 & 2.40 & 4.97 & 2.77 & $3.42^{*}$ & 2.00 \\
\hline Lgr & $5.93^{*}$ & 1.81 & $3.62^{*}$ & 1.26 & $3.97 *$ & 1.16 & b.q* & b.q. \\
\hline L & $0.96^{*}$ & 0.19 & $0.46^{*}$ & 0.13 & $0.54^{*}$ & 0.16 & b.q* & b.q. \\
\hline SPA & 6.07 & 2.50 & 5.22 & 3.15 & 5.53 & 2.85 & 3.85 & 2.06 \\
\hline SF & $6.89 *$ & 1.90 & $4.07 *$ & 1.37 & $4.52^{*}$ & 2.85 & $0.00^{*}$ & 0.00 \\
\hline SPP & $12.96^{*}$ & 3.81 & $9.29^{*}$ & 4.16 & $10.05^{*}$ & 3.70 & $3.85^{*}$ & 2.06 \\
\hline
\end{tabular}

b.q., below LQ; *Kruskal-Wallis test, $\mathrm{p}<0.05$. 
A)
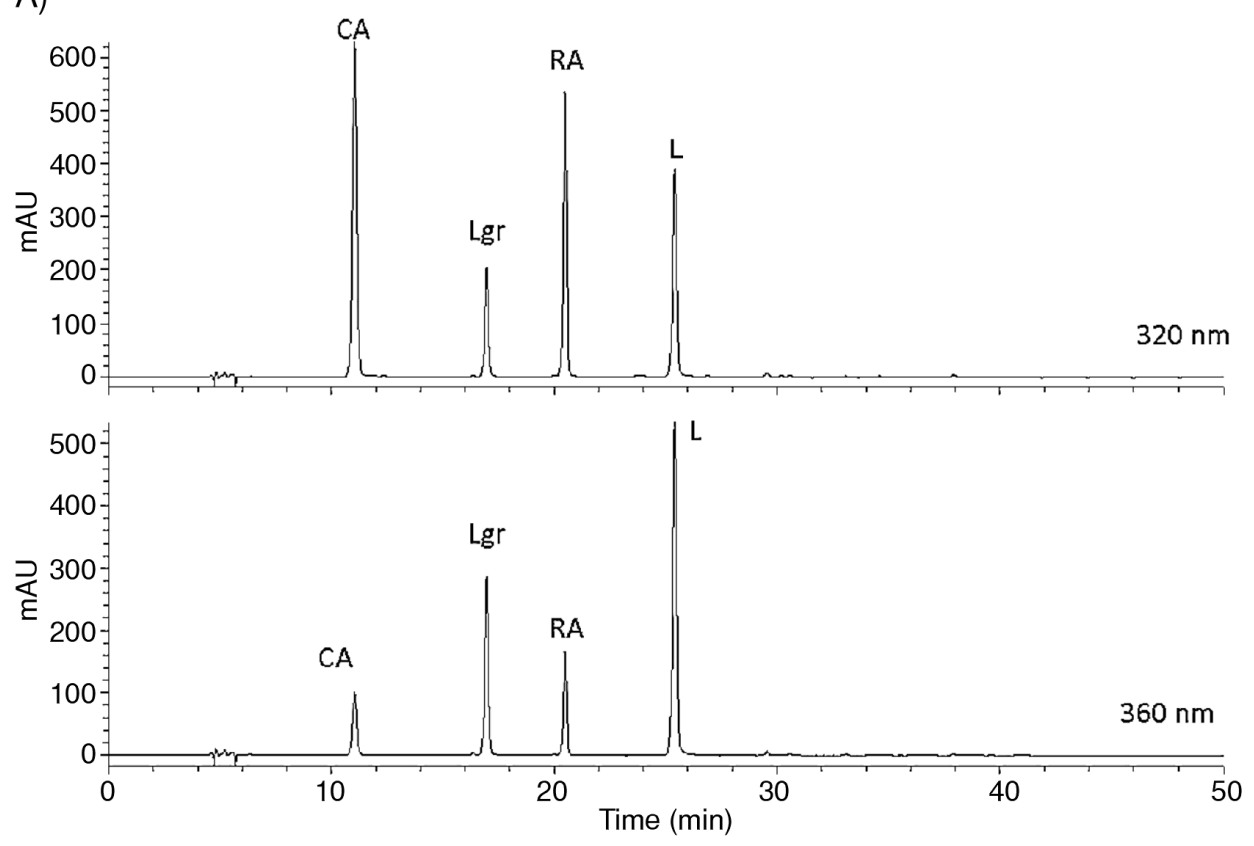

B)

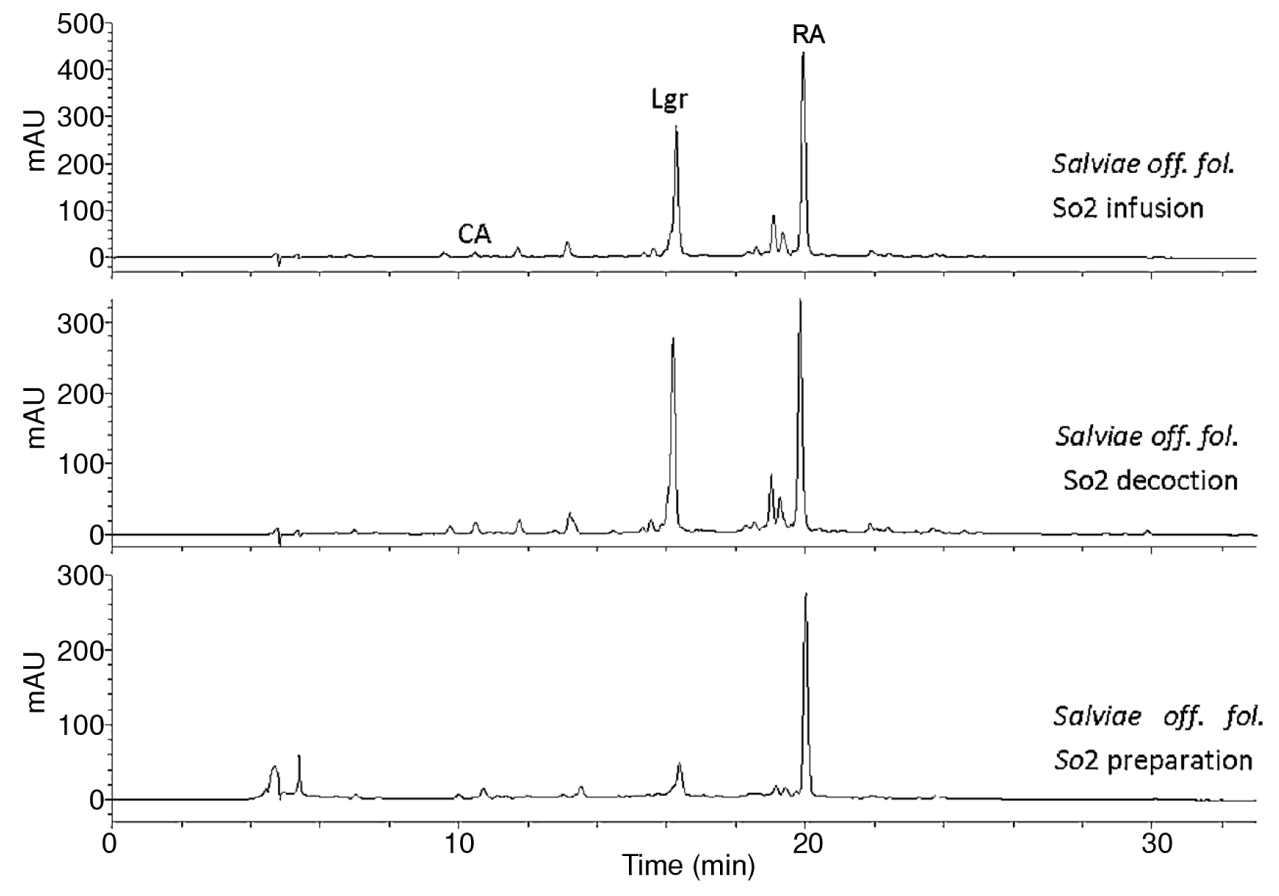

Figure 1. HPLC chromatograms of standard compounds at $0.05 \mathrm{mg} / \mathrm{g}$ (A), and Salviae off. fol. infusion, decoction and magistral preparation $(\mathrm{B}, \lambda=320 \mathrm{~mm})$.

(9-12). Podbielski \& Rostafiński (13) cite sets for throat rinsing mixtures with borax and tannin-rich raw herbal drugs. Moreover, gargles based on borax with other herbal extracts containing Salvia off. fol. are reported there. Similarly, prescriptions for dif- ferent tannin sources (Quercus cortex - oak bark, Tanninum) together with aluminum salts, borax, and glycerin gargles were found elsewhere $(14,15)$. Both aluminum and borate salts, as well as sage leaf preparations, have been used separately in oral dis- 
eases $(9,13,14)$. To be sure that the maximal amount of reference material was analyzed, available studies and manuals that were standard in Poland and Europe were checked (16-24). However, we did not find any information on the use of similar provisions in them.

Salviae off. fol. infusions and decoctions from seven different medicinal products So1-So7 were based on the description in the general monograph in Polish Pharmacopoeia XI (25). The productivities of both hot water extractions (Inf., Dec.) vs. 50\% aq. methanol ultrasonic extraction (Ex50Me) from the tested common sage leaves were compared. Extraction supported by an ultrasonic bath is a widely used technique in the process of preparing samples for testing polyphenol content in plant material. Standardization of the process of extraction of raw materials from Lamiaceae, including Salviae off. fol., is described by Fecka and Turek (7). Polyphenolic compounds were determined by the previously developed and validated HPLC-DAD method $(7,8)$. Linearity parameters obtained for this study are presented in Table 1 .

Phenolic acids were determined at $320 \mathrm{~nm}$ and flavonoids (flavones) at $360 \mathrm{~nm}$. Peaks of polyphenols were identified $(7,8,26)$ by comparison of their retention times $\left(t_{R}\right)$ and UV-Vis absorption spectrum profiles with appropriate parameters obtained from authentic standards (Figs. $1 \mathrm{~A}$ and B).

The mean contents of four analyzed polyphenols expressed as milligrams in $1 \mathrm{~g}$ of common sage leaves (So1-So7) used for the preparation of aq. methanolic extracts, infusions, decoctions and magistral products (Ex50Me, Inf., Dec., Prep.) are presented in Table 2.

The highest content of polyphenols sum (SPP) was determined for $50 \%$ aq. methanolic extract (12.96 mg/g), then for the decoction $(10.05 \mathrm{mg} / \mathrm{g}$ ) and the infusion $(9.29 \mathrm{mg} / \mathrm{g})$, and the lowest for the magistral preparation $(3.85 \mathrm{mg} / \mathrm{g})$. A similar trend was observed in relation to the content of the sum of two analyzed groups of polyphenols (phenolic acids - SPA, and flavonoids - SF) and individual components (CA, RA, L, Lgr). The main polyphenolic ingredients of Salviae off. fol. were rosmarinic acid and luteolin 7-O- $\beta$-glucuronide. The RA predominance was observed in the infusion, decoction and magistral preparation, whereas $50 \%$ aq. methanolic extract was characterized by similar levels of RA (on average $6.22 \mathrm{mg} / \mathrm{g}$, range 4.54-13.30 mg/g) and Lgr (on average $5.93 \mathrm{mg} / \mathrm{g}$, range $4.33-8.82 \mathrm{mg} / \mathrm{g}$ ). Free caffeic acid and luteolin aglycone were determined at a much lower concentration (below 0.60 and $0.96 \mathrm{mg} / \mathrm{g}$ respectively). Comparing the con- tents of analyzed polyphenols (SPA, SF, SPP), it was confirmed that their levels in the decoction were higher than in the infusion. Martins et al. (27) also achieved similar results. However, in relation to the $50 \%$ aq. methanolic extract (DER $1: 200, \mathrm{~m} / \mathrm{v}$ ), the contents of main RA and Lgr components were even lower by half in hot water extracts prepared from common sage leaves. The Kruskal-Wallis test showed significant statistical differences $(p<0.05)$ in the content of both flavonoid and polyphenol sums, and the following individual compounds: Lgr and $\mathrm{L}$ between the analyzed magistral preparation and infusion, decoction and 50\% methanolic extract, as well as RA only between magistral preparation and 50\% methanolic extract (Table 2). The statistically significant difference in the concentration of CA between infusion and decoction was also observed. This difference resulted mainly from the use of different proportions of plant matter to the final product (for galenic forms DER was $1: 10$, $\mathrm{m} / \mathrm{m})$. Rosmarinic acid and luteolin 7-O- $\beta$-glucuronide in infusions and decoctions reached on average $46 \pm 6 \%$ and $68 \pm 6 \%$ (RA) as well as $69 \pm$ $9 \%$ and $70 \pm 6 \%$ (Lgr) of the content calculated for aq. methanolic extracts. In comparison to other preparations of Salviae off. fol., the magistral preparation stood out by the lack of flavonoids (content below LQ), which were precipitated as yellowish sediment. The presence of hardly soluble sediment in aqueous medium was observed directly after preparation. This phenomenon was known in relation to the analyzed prescription formulation. Therefore, pharmacists were obliged to include the information "mix before use" on the label of this sage leaf magistral preparation. The content of phenolic acids in the magistral preparation also decreased in comparison to the initial decoction by about $30 \%$ (for RA on average $33 \pm 11 \%$, CA on average $29 \pm 10 \%$ ). Analysis of the composition of the formula for the sage leaf magistral preparation suggests the possibility of the formation of complex compounds with aluminum(III) ions and boric acid. The interactions of sage polyphenols with the other components of the magistral preparation were studied using a model mixture of 4 standards (Mix4) at a concentration of $0.49-0.64 \mathrm{mg} / \mathrm{mL}$ (Table 3 ) and aqueous solutions of glycerol (s2), boric acid (s3), aluminum(III) acetotartrate (s4) and their combination (s5) in proportions $(\mathrm{m} / \mathrm{m})$ resulting from the composition of the prescription formulation (Fig. 2A).

The contents of each of the compounds determined in particular model mixtures were compared to the reference solution ( $\mathrm{s} 1)$ prepared by dilution of Mix4 with water-methanol $(1+1, \mathrm{~m} / \mathrm{m})$ in the same 
ratio $(1: 10, \mathrm{~m} / \mathrm{m})$. There were no changes in the content of polyphenols in the water-glycerol solution; the model mixture with s2 did not change the color or show any turbidity. Mixtures of s3, s4, and s5 were characterized by a lower content of individual compounds and visual changes (detected for s4 and s5). They varied in color from yellowish to fluorescent intense yellow. The presence of $\mathrm{Al}(\mathrm{III})$ ions in the solution resulted in the precipitation of a subtle precipitate (in the colloid form). Significantly lower contents in ALTACET solutions ( 44 and s5) were recorded for flavonoids (for Lgr by ca. $73 \%$, for $\mathrm{L}$ by ca. $60 \%$ ), whereas the content of phenolic acids decreased to a moderate extent (for RA by ca. $17 \%$, for CA by ca. $25 \%$ ). The addition of boric acid did not cause turbidity, the content of phenolic acids remained at a similar level (decrease in RA by ca. $10 \%$, CA by ca. $5 \%$ ), while the level of flavonoids decreased moderately (Lgr by ca. 16\%, L by ca. $34 \%$ ). On the chromatograms of mixtures with s4 and $s 5$, a few additional peaks ( $t_{R}$ up to 7 min., Fig. 2A) from more polar and soluble polyphenol-aluminum(III) complexes were observed. Two of them were well separated ( $\mathrm{Al}(\mathrm{III})$ complexes 1 and 3 at $\mathrm{t}_{\mathrm{R}}$ -4.28 and $6.28 \mathrm{~min}$ ), while three others ( $\mathrm{Al}(\mathrm{III})$ complexes $2+$ at $t_{R}-4.50-5.15 \mathrm{~min}$ ) were only partially separated and were close to each other. The first peak showed a UV-Vis absorption spectrum analogous to RA and CA (Fig. 2B), while all the other peaks were characterized by UV-Vis profiles typical for flavones ( $\mathrm{L}$ and Lgr, Fig. 2B), but the bands I were shifted towards the long-wavelength

A)
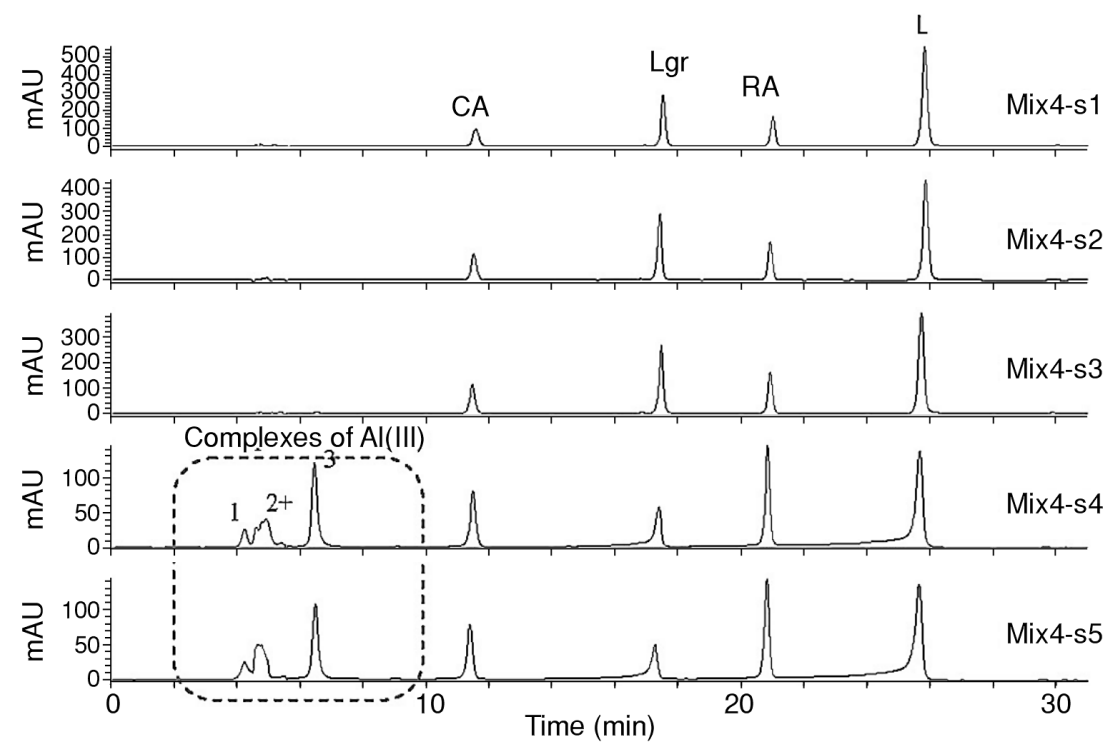

B)
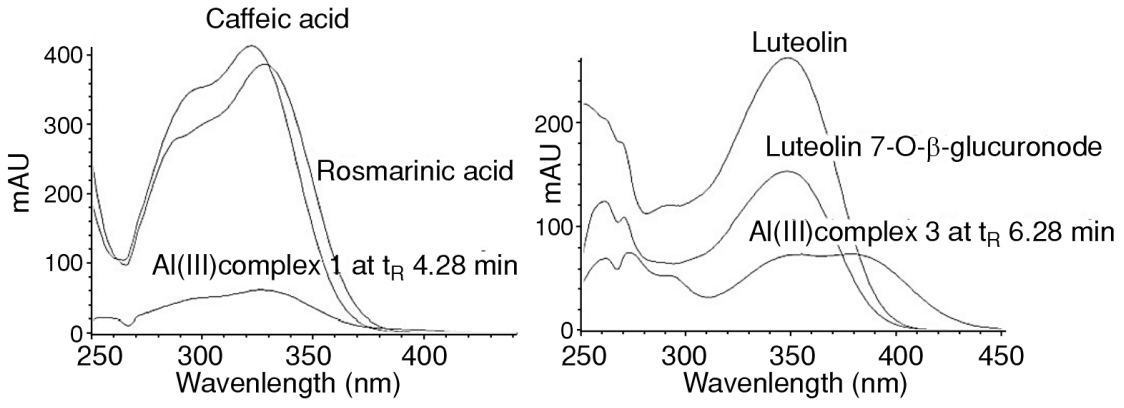

Figure 2. HPLC chromatograms of model mixtures of standards (Mix4) with aqueous solutions of glycerol (s2; Aq-GLYCEROL, 49 + 1), boric acid (s3; Aq-BORIC ACID, $49.5+0.5$ ), aluminum(III) acetotartrate (s4; Aq-ALTACET, $49.5+0.5)$ and their combination (s5; AqBORIC ACID-ALTACET-GLYCEROL, $40+0.5+0.5+9)$ at a ratio of $1: 10(\mathrm{~m} / \mathrm{m}), 360 \mathrm{~nm}(\mathrm{~A})$; and UV-Vis absorption spectra of standards and detected polyphenol-Al(III) complexes (B). 
region from 350 to $385 \mathrm{~nm}$ (at $\mathrm{pH} \sim 3.9$ ). The structure of sage polyphenol complexes with aluminum(III) and boric acid was next studied by ESIMS experiments.

Polyphenols possess a highly conjugated aromatic system and therefore show intense and characteristic absorption and fluorescence spectra. Chelation with various metal ions causes spectral shifts that can be correlated with polyphenolic structure. Moreover, the UV-Vis absorption spectra of flavonoids in the presence of $\mathrm{Al}(\mathrm{III})$ are commonly used to distinguish compounds containing either a free 5-OH or 3-OH group. The chelating ability of different flavonoids and phenolic acids have been studied previously many times $(27,28)$. Luteolin$\mathrm{Al}(\mathrm{III})$ coordination complexes were investigated by UV-Vis, fluorescence, IR, FT-Raman and ESI-MS spectroscopy (29-31). Interactions of caffeic acid and caffeate with $\mathrm{Al}(\mathrm{III})$ were also examined (32, 33).

In the magistral preparation of sage leaf (prepared from hot water extracts described above), the molar ratio of the main flavonoid Lgr to boric acid (BA) was about $1: 187$ while to aluminum(III) ace-

Table 3. Analysis of polyphenols interaction in model mixtures with different solvents and components $(\mathrm{n}=3)$.

\begin{tabular}{|c|c|c|c|c|c|c|}
\hline \multirow{2}{*}{$\begin{array}{l}\text { Model } \\
\text { mixtures }\end{array}$} & $\begin{array}{c}\text { Final } \\
\text { concentration }^{1}\end{array}$ & $\mathrm{~s} 1^{2}$ & $\mathrm{~s} 2^{2}$ & $\mathrm{~s} 3^{2}$ & $s 4^{2}$ & $\mathrm{~s} 5^{2}$ \\
\hline & \multicolumn{6}{|c|}{$[\mathrm{mg} / \mathrm{g}](\mathrm{SD})$} \\
\hline $\mathrm{CA}$ & 0.49 & $0.50(0.02)$ & $0.50(0.01)$ & $0.47(0.04)$ & $0.38(0.02)$ & $0.37(0.03)$ \\
\hline RA & 0.64 & $0.65(0.02)$ & $0.63(0.01)$ & $0.58(0.06)$ & $0.53(0.03)$ & $0.54(0.03)$ \\
\hline Lgr & 0.51 & $0.48(0.01)$ & $0.46(0.01)$ & $0.41(0.04)$ & $0.13(0.00)$ & $0.13(0.02)$ \\
\hline $\mathrm{L}$ & 0.60 & $0.62(0.02)$ & $0.51(0.03)$ & $0.41(0.06)$ & $0.25(0.01)$ & $0.26(0.01)$ \\
\hline \multirow[t]{5}{*}{ SOLVENTS: } & s1 & \multicolumn{3}{|c|}{$\mathrm{Aq}-\mathrm{MeOH}$} & $(1+1)$ & {$[\mathrm{m} / \mathrm{m}]$} \\
\hline & s2 & \multicolumn{3}{|c|}{ Aq-GLYCEROL } & $(41+9)$ & {$[\mathrm{m} / \mathrm{m}]$} \\
\hline & s3 & \multicolumn{3}{|c|}{ Aq-BORIC ACID } & $(49.5+0.5)$ & {$[\mathrm{m} / \mathrm{m}]$} \\
\hline & s4 & \multicolumn{3}{|c|}{ Aq-ALTACET } & $(49.5+0.5)$ & {$[\mathrm{m} / \mathrm{m}]$} \\
\hline & s5 & \multicolumn{3}{|c|}{ Aq-BORIC ACID-ALTACET-GLYCEROL } & $(40+0.5+0.5+9)$ & {$[\mathrm{m} / \mathrm{m}]$} \\
\hline
\end{tabular}

${ }^{1}$ calculated values, ${ }^{2}$ experimental values.
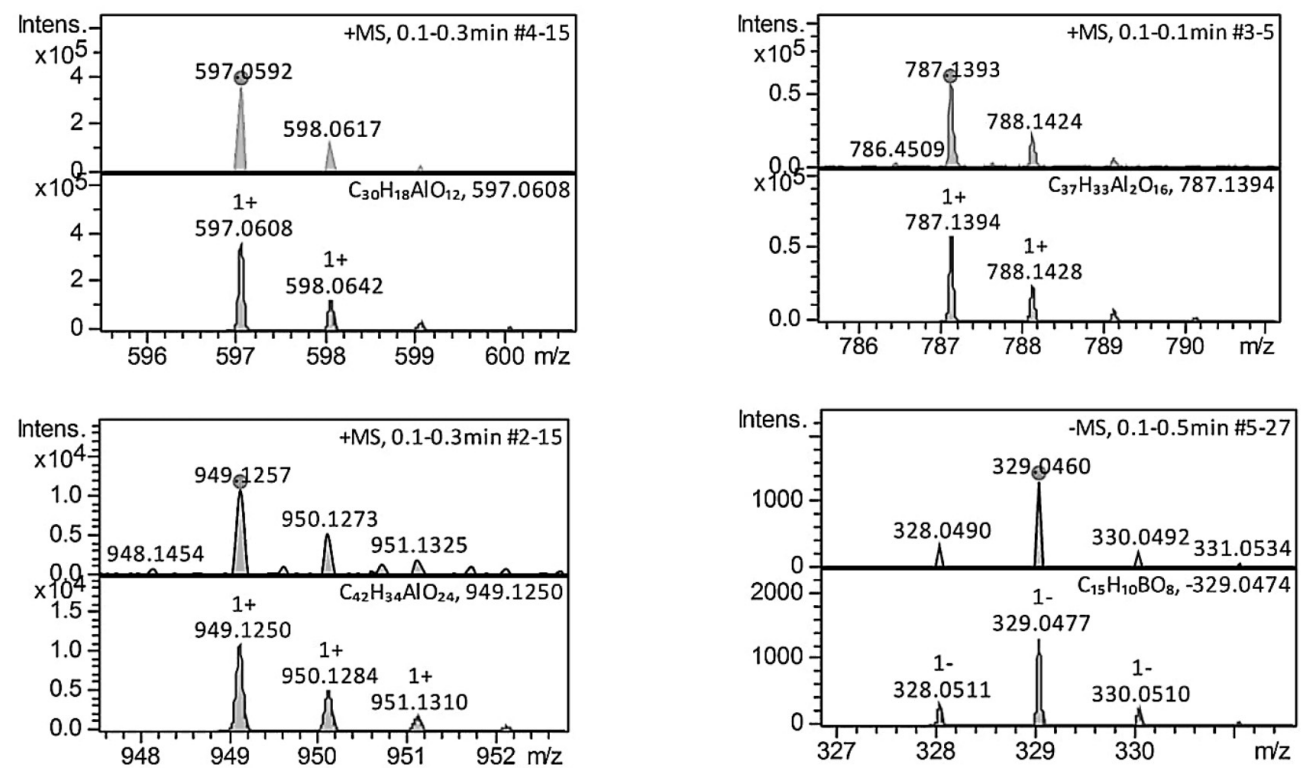

Figure 3. Representative ESI-MS spectra of analyzed polyphenolic complexes m methanol: $\mathrm{L}_{2-} \mathrm{Al}(\mathrm{III})$ with $\mathrm{m} / \mathrm{z} 597, \mathrm{Lgr} 2 \mathrm{Al}(\mathrm{III})$ with $m / z$ 949, RA-Al(III) with $\mathrm{m} / \mathrm{z} 787$, and L-BA with $\mathrm{m} / \mathrm{z} 328$. 
Table 4. Mass spectra analysis and proposed formulas for ions observed in binary mixtures of luteolin (L at $50 \mu$ mol), luteolin 7-O- $\beta$-glucuronide (Lgr at $50 \mu \mathrm{mol}$ ) or rosmarinic acid (RA at $50 \mu \mathrm{mol}$ ) with aluminum(III) acetotartrate (at $100 \mu \mathrm{mol})$ in methanol, measured in positive mode.

\begin{tabular}{|c|c|c|c|c|c|}
\hline Compound & $\begin{array}{c}\text { Cumulative } \\
\text { neutral formula }\end{array}$ & Proposed ion formula & Meas. $m / z$ & Calc. $m / z$ & $\begin{array}{c}\text { Err. } \\
{[\mathrm{ppm}]}\end{array}$ \\
\hline $\mathrm{L}$ & $\mathrm{C}_{15} \mathrm{H}_{10} \mathrm{O}_{6}$ & {$\left[\mathrm{C}_{15} \mathrm{H}_{10} \mathrm{O}_{6}+\mathrm{H}\right]^{+}$} & 287.0551 & 287.0550 & -0.3 \\
\hline $\mathrm{L}_{2}-\mathrm{Al}(\mathrm{III})$ complex & $\mathrm{C}_{30} \mathrm{H}_{17} \mathrm{AlO}_{12}$ & {$\left[\left(\mathrm{C}_{15} \mathrm{H}_{10} \mathrm{O}_{6}\right)_{2}+\mathrm{Al}(\mathrm{OH})_{3}-3 \mathrm{H}_{2} \mathrm{O}+\mathrm{H}\right]^{+}$} & 597.0592 & 597.0608 & 2.7 \\
\hline Lgr & $\mathrm{C}_{21} \mathrm{H}_{18} \mathrm{O}_{12}$ & {$\left[\mathrm{C}_{21} \mathrm{H}_{18} \mathrm{O}_{12}+\mathrm{H}\right]^{+}$} & 463.0876 & 463.0871 & -1.1 \\
\hline $\mathrm{Lgr}_{2}-\mathrm{Al}(\mathrm{III})$ complex & $\mathrm{C}_{42} \mathrm{H}_{33} \mathrm{AlO}_{24}$ & {$\left[\left(\mathrm{C}_{21} \mathrm{H}_{18} \mathrm{O}_{12}\right)_{2}+\mathrm{Al}(\mathrm{OH})_{3}-3 \mathrm{H}_{2} \mathrm{O}+\mathrm{H}\right]^{+}$} & 949.1257 & 949.1250 & -0.7 \\
\hline RA & $\mathrm{C}_{18} \mathrm{H}_{16} \mathrm{O}_{8}$ & {$\left[\mathrm{C}_{18} \mathrm{H}_{16} \mathrm{O}_{8}+\mathrm{H}\right]^{+}$} & 361.0923 & 361.0918 & 1.6 \\
\hline RA-Al(III) complex & $\mathrm{C}_{18} \mathrm{H}_{17} \mathrm{AlO}_{9}$ & {$\left[\mathrm{C}_{18} \mathrm{H}_{16} \mathrm{O}_{8}+\mathrm{Al}(\mathrm{OH})_{3}-2 \mathrm{H}_{2} \mathrm{O}+3 \mathrm{H}\right]^{+}$} & 405.0751 & 405.0761 & 1.0 \\
\hline $\mathrm{RA}_{2}-\mathrm{Al}(\mathrm{III})_{2}$ complex & $\mathrm{C}_{36} \mathrm{H}_{28} \mathrm{Al}_{2} \mathrm{O}_{17}$ & {$\left[\left(\mathrm{C}_{18} \mathrm{H}_{16} \mathrm{O}_{8}\right)_{2}+2 \mathrm{Al}(\mathrm{OH})_{3}-5 \mathrm{H}_{2} \mathrm{O}+\mathrm{H}\right]^{+}$} & 787.1093 & 787.1030 & -6.4 \\
\hline
\end{tabular}

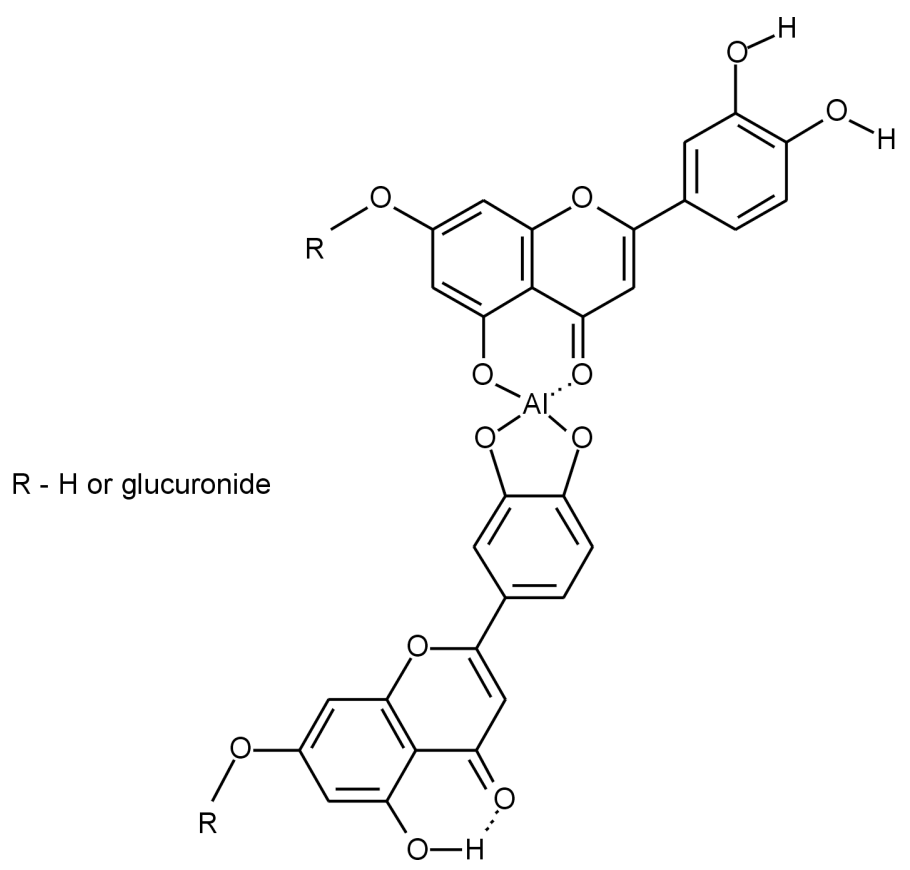

Figure 4. Proposed structures of luteolin-Al(III) and luteolin 7-O-ß3-glucuronide-Al(III) coordination complexes at the stoichiometric ratio $2: 1$ - corresponding to protonated molecules $\left[\left(\mathrm{L}_{2} \text { or } \mathrm{Lgr}_{2}+\mathrm{Al}(\mathrm{OH})_{3}-3 \mathrm{H}_{2} \mathrm{O}+\mathrm{H}\right]^{+}\right.$with $\mathrm{m} / z 597$ and 949 , respectively.

totartrate (Al(III)AcT from ALTACET) it was about $1: 50$. The RA molar ratio to BA was about $1: 118$ and to $\mathrm{Al}$ (III)AcT about $1: 30$. To enhance the detectability of analyzed complexes by ESI-MS the molar ratio of polyphenols was increased to a higher degree $(1: 2)$.

ESI-MS measurements provide direct evidence for formation of complexes between sage polyphenols, and both boric acid and aluminum(III) acetotartrate. The results of the qualitative analysis of complexes resulting in binary mixtures of CA, RA, L, Lgr (each $50 \mu \mathrm{mol})$ with BA $(100 \mu \mathrm{mol})$ or $\mathrm{Al}(\mathrm{III}) \mathrm{AcT}$ $(100 \mu \mathrm{mol})$ are presented in Tables 4 and 5. Flavoneboric acid interactions were investigated by ESI-MS in negative mode. BA can chelate with the flavonoids to form more soluble complex anions (35). Observed complexes with boric acid resembled those described previously (36). For analysis of luteolin-Al(III) and luteolin-7-O- $\beta$-glucuronide-Al(III) complexes, the positive mode was more useful. The analysis strategy was based on a previous study (29). Rosmarinic acid and caffeic acid were similarly examined for complex formation in both modes. Representative examples of identified pseudomolecular ions of the main complexes are presented in Figure 3. The mass-to-charge ratio $(\mathrm{m} / \mathrm{z})$ of the detected $\mathrm{MS}^{+}$ions (Table 4) clearly showed the presence of two species of stoichiometry polyphenol-Al(III); $2: 1$ for $\mathrm{Lgr}(\mathrm{m} / \mathrm{z} 949.1257)$ and $\mathrm{L}(\mathrm{m} / z$ 597.0592), and $1: 1$ for RA $(\mathrm{m} / \mathrm{z} 405.0751$ and 787.1393). 
Table 5. Mass spectra analysis and proposed formulas for ions observed in binary mixtures of luteolin ( $\mathrm{L}$ at $50 \mu \mathrm{mol})$ or luteolin 7-O- $\beta$ glucuronide ( $\mathrm{Lgr}$ at $50 \mu \mathrm{mol})$ and boric acid (BA at $100 \mu \mathrm{mol})$ in methanol, measured in negative mode.

\begin{tabular}{|l|c|l|c|c|c|}
\hline \multicolumn{1}{|c|}{ Compound } & $\begin{array}{c}\text { Cumulative } \\
\text { neutral formula }\end{array}$ & \multicolumn{1}{|c|}{ Proposed ion formula } & Meas. $m / z$ & Calc. $m / z$ & $\begin{array}{c}\text { Err. } \\
\text { [ppm] }\end{array}$ \\
\hline $\mathrm{L}$ & $\mathrm{C}_{15} \mathrm{H}_{10} \mathrm{O}_{6}$ & {$\left[\mathrm{C}_{15} \mathrm{H}_{10} \mathrm{O}_{6}-\mathrm{H}\right]^{-}$} & 285.0403 & 285.0405 & 0.7 \\
\hline $\mathrm{L}-\mathrm{BA}$ complex & $\mathrm{C}_{15} \mathrm{H}_{11} \mathrm{BO}_{8}$ & {$\left[\mathrm{C}_{15} \mathrm{H}_{10} \mathrm{O}_{6}+\mathrm{B}(\mathrm{OH})_{3}-\mathrm{H}_{2} \mathrm{O}-\mathrm{H}\right]^{-}$} & 328.0490 & 328.0511 & 6.4 \\
\hline L-BA complex & $\mathrm{C}_{17} \mathrm{H}_{15} \mathrm{BO}_{8}$ & {$\left[\mathrm{C}_{15} \mathrm{H}_{10} \mathrm{O}_{6}+\mathrm{B}(\mathrm{OH})_{3}+2 \mathrm{CH}_{3} \mathrm{OH}-3 \mathrm{H}_{2} \mathrm{O}-\mathrm{H}\right]^{-}$} & 356.0811 & 356.0824 & 3.7 \\
\hline $\mathrm{L}_{2}-\mathrm{BA}$ complex & $\mathrm{C}_{31} \mathrm{H}_{21} \mathrm{BO}_{13}$ & {$\left[\left(\mathrm{C}_{15} \mathrm{H}_{10} \mathrm{O}_{6}\right)_{2}+\mathrm{B}(\mathrm{OH})_{3}+\mathrm{CH}_{3} \mathrm{OH}-3 \mathrm{H}_{2} \mathrm{O}-\mathrm{H}\right]^{-}$} & 610.0925 & 610.1039 & 18.7 \\
\hline Lgr & $\mathrm{C}_{21} \mathrm{H}_{18} \mathrm{O}_{12}$ & {$\left[\mathrm{C}_{21} \mathrm{H}_{18} \mathrm{O}_{12}-\mathrm{H}\right]^{-}$} & 461.0724 & 461.0726 & 0.4 \\
\hline Lgr-BA complex & $\mathrm{C}_{21} \mathrm{H}_{17} \mathrm{BO}_{13}$ & {$\left[\mathrm{C}_{21} \mathrm{H}_{18} \mathrm{O}_{12}+\mathrm{B}(\mathrm{OH})_{3}-2 \mathrm{H}_{2} \mathrm{O}-\mathrm{H}\right]^{-}$} & 486.0703 & 486.0726 & 4.7 \\
\hline Lgr-BA complex & $\mathrm{C}_{21} \mathrm{H}_{19} \mathrm{BO}_{14}$ & {$\left[\mathrm{C}_{21} \mathrm{H}_{18} \mathrm{O}_{12}+\mathrm{B}(\mathrm{OH})_{3}-\mathrm{H}_{2} \mathrm{O}-\mathrm{H}\right]^{-}$} & 504.0790 & 504.0831 & 8.1 \\
\hline Lgr-BA complex & $\mathrm{C}_{21} \mathrm{H}_{16} \mathrm{~B}_{2} \mathrm{O}_{14}$ & {$\left[\mathrm{C}_{21} \mathrm{H}_{18} \mathrm{O}_{12}+2 \mathrm{~B}(\mathrm{OH})_{3}-4 \mathrm{H}_{2} \mathrm{O}-\mathrm{H}\right]^{-}$} & 511.0724 & 511.0726 & 0.4 \\
\hline Lgr-BA 2 complex & $\mathrm{C}_{21} \mathrm{H}_{20} \mathrm{~B}_{2} \mathrm{O}_{16}$ & {$\left[\mathrm{C}_{21} \mathrm{H}_{18} \mathrm{O}_{12}+2 \mathrm{~B}(\mathrm{OH})_{3}-2 \mathrm{H}_{2} \mathrm{O}-\mathrm{H}\right]^{-}$} & 547.0940 & 547.0937 & -0.5 \\
\hline Lgr-BA ${ }_{3}$ complex & $\mathrm{C}_{21} \mathrm{H}_{19} \mathrm{~B}_{3} \mathrm{O}_{17}$ & {$\left[\mathrm{C}_{21} \mathrm{H}_{18} \mathrm{O}_{12}+3 \mathrm{~B}(\mathrm{OH})_{3}-4 \mathrm{H}_{2} \mathrm{O}-\mathrm{H}\right]^{-}$} & 572.0912 & 572.0938 & 4.5 \\
\hline Lgr- $\mathrm{BA}_{4}$ complex & $\mathrm{C}_{21} \mathrm{H}_{20} \mathrm{~B}_{4} \mathrm{O}_{19}$ & {$\left[\mathrm{C}_{21} \mathrm{H}_{18} \mathrm{O}_{12}+4 \mathrm{~B}(\mathrm{OH})_{3}-5 \mathrm{H}_{2} \mathrm{O}-\mathrm{H}\right]^{-}$} & 615.0986 & 615.1044 & 9.4 \\
\hline
\end{tabular}

Table 6. Stability of rosmarinic acid $[\mathrm{mg} / \mathrm{g}]$.

\begin{tabular}{|c|c|c|c|c|c|c|c|c|}
\hline $\begin{array}{c}\text { RA } \\
\text { content }\end{array}$ & $\begin{array}{c}\text { Prep. } \\
\text { So1 }{ }^{1}\end{array}$ & $\begin{array}{c}\text { Prep. } \\
\text { So2.1 }\end{array}$ & $\begin{array}{c}\text { Prep. } \\
\text { So2.2 }\end{array}$ & $\begin{array}{c}\text { Prep. } \\
\text { So3.1 }\end{array}$ & $\begin{array}{c}\text { Prep. } \\
\text { So3.2 }\end{array}$ & $\begin{array}{c}\text { Prep. } \\
\text { So7.1 }\end{array}$ & $\begin{array}{c}\text { Prep. } \\
\text { So7.2 }\end{array}$ & $\begin{array}{c}\text { Mean } \\
\text { Prep. So2-So7 }\end{array}$ \\
\hline 0-day & 2.31 & 6.71 & 6.69 & 1.87 & 1.82 & 4.05 & 3.91 & 4.18 \\
\hline 1-day & 2.57 & 7.26 & 5.83 & 1.99 & 1.72 & 3.64 & 3.83 & 4.04 \\
\hline 2-day & 2.39 & 6.92 & 5.87 & 1.78 & 1.76 & 3.65 & 3.73 & 3.95 \\
\hline 3-day & 2.30 & 5.75 & 6.01 & 1.78 & 1.72 & 3.78 & 3.56 & 3.77 \\
\hline 4-day & 2.29 & 6.72 & 5.81 & 1.73 & 1.56 & 3.51 & 3.60 & 3.82 \\
\hline 7-day & 2.28 & 6.72 & 5.75 & 1.69 & 1.58 & 3.58 & 3.60 & 3.82 \\
\hline Mean & 2.36 & 6.68 & $5.99 *$ & 1.81 & 1.69 & 3.70 & 3.71 & 3.93 \\
\hline SD & 0.10 & 0.46 & 0.32 & 0.10 & 0.10 & 0.18 & 0.13 & 0.14 \\
\hline CV\% & 4.35 & 6.87 & 5.36 & 5.34 & 5.66 & 4.75 & 3.52 & 3.67 \\
\hline
\end{tabular}

${ }^{1} \mathrm{n}=6 \times 3 ;{ }^{2} \mathrm{n}=3 ; *$ Spearman test, $\mathrm{p}<0.05$.

Table 7. Stability of caffeic acid $[\mathrm{mg} / \mathrm{g}]$.

\begin{tabular}{|c|c|c|c|c|c|c|c|c|}
\hline $\begin{array}{c}\text { CA } \\
\text { content }\end{array}$ & $\begin{array}{c}\text { Prep. } \\
\text { So1 }\end{array}$ & $\begin{array}{c}\text { Prep. } \\
\text { So2.1 }\end{array}$ & $\begin{array}{c}\text { Prep. } \\
\text { So2.2 }\end{array}$ & $\begin{array}{c}\text { Prep. } \\
\text { So3.1 }\end{array}$ & $\begin{array}{c}\text { Prep. } \\
\text { So3.2 }\end{array}$ & $\begin{array}{c}\text { Prep. } \\
\text { So7.1 }\end{array}$ & $\begin{array}{c}\text { Prep. } \\
\text { So7.2 }\end{array}$ & $\begin{array}{c}\text { Mean } \\
\text { Prep. So2-So7 }\end{array}$ \\
\hline 0-day & 0.37 & 0.49 & 0.51 & 0.31 & 0.31 & 0.43 & 0.40 & 0.41 \\
\hline 1-day & 0.41 & 0.51 & 0.45 & 0.34 & 0.30 & 0.40 & 0.40 & 0.40 \\
\hline 2-day & 0.39 & 0.51 & 0.49 & 0.32 & 0.32 & 0.41 & 0.41 & 0.41 \\
\hline 3-day & 0.37 & 0.46 & 0.47 & 0.33 & 0.28 & 0.42 & 0.39 & 0.39 \\
\hline 4-day & 0.40 & 0.52 & 0.44 & 0.32 & 0.27 & 0.35 & 0.38 & 0.38 \\
\hline 7-day & 0.40 & 0.5 & 0.48 & 0.33 & 0.28 & 0.42 & 0.40 & 0.40 \\
\hline Mean & 0.39 & 0.50 & 0.47 & 0.33 & 0.29 & 0.41 & 0.40 & 0.40 \\
\hline SD & 0.01 & 0.02 & 0.02 & 0.01 & 0.02 & 0.03 & 0.01 & 0.01 \\
\hline CV\% & 3.53 & 3.91 & 4.98 & 2.93 & 5.68 & 6.49 & 2.23 & 2.60 \\
\hline
\end{tabular}

${ }^{1} \mathrm{n}=6 \times 3 ;{ }^{2} \mathrm{n}=3$. 
Table 8. Stability of detected polyphenols expressed as a sum of CA and RA [SPA, mg/g].

\begin{tabular}{|c|c|c|c|c|c|c|c|c|}
\hline $\begin{array}{c}\text { TPP } \\
\text { content }\end{array}$ & $\begin{array}{c}\text { Prep. } \\
\text { So1 }\end{array}$ & $\begin{array}{c}\text { Prep. } \\
\text { So2.1 }\end{array}$ & $\begin{array}{c}\text { Prep. } \\
\text { So2.2 }\end{array}$ & $\begin{array}{c}\text { Prep. } \\
\text { So3.1 }\end{array}$ & $\begin{array}{c}\text { Prep. } \\
\text { So3.2 }\end{array}$ & $\begin{array}{c}\text { Prep. } \\
\text { So7.1 }{ }^{2}\end{array}$ & $\begin{array}{c}\text { Prep. } \\
\text { So7.2 }\end{array}$ & $\begin{array}{c}\text { Mean } \\
\text { Prep. So2-So7 }\end{array}$ \\
\hline 0-day & 2.68 & 7.20 & 7.20 & 2.19 & 2.14 & 4.48 & 4.31 & 4.59 \\
\hline 1-day & 2.98 & 7.77 & 6.28 & 2.33 & 2.02 & 4.04 & 4.24 & 4.45 \\
\hline 2-day & 2.78 & 7.43 & 6.36 & 2.10 & 2.07 & 4.06 & 4.13 & 4.36 \\
\hline 3-day & 2.66 & 6.21 & 6.48 & 2.11 & 2.00 & 4.20 & 3.94 & 4.16 \\
\hline 4-day & 2.69 & 7.24 & 6.25 & 2.05 & 1.82 & 3.86 & 3.99 & 4.20 \\
\hline 7-day & 2.68 & 7.22 & 6.23 & 2.03 & 1.86 & 4.00 & 4.00 & 4.22 \\
\hline Mean & 2.75 & 7.18 & $6.47 *$ & 2.13 & 1.99 & 4.11 & 4.10 & 4.33 \\
\hline SD & 0.11 & 0.48 & 0.34 & 0.10 & 0.11 & 0.19 & 0.14 & 0.15 \\
\hline CV\% & 4.05 & 6.63 & 5.23 & 4.70 & 5.56 & 4.74 & 3.33 & 3.49 \\
\hline
\end{tabular}

${ }^{1} \mathrm{n}=6 \times 3 ;{ }^{2} \mathrm{n}=3 ; *$ Spearman test, $\mathrm{p}<0.05$.

Complexes with boric acid were proved only for flavones, and observed $\mathrm{MS}^{-}$ions suggested flavone-BA stoichiometry $1: 1$ and $2: 1$ for $\mathrm{L}$, and $1: 1,1: 2,1: 3$ and $1: 4$ for Lgr (Table 5). Nevertheless, pseudomolecular ions of complexes in mass spectra of binary mixtures of CA, RA, L and Lgr with $\mathrm{Al}(\mathrm{III}) \mathrm{AcT}$ or $\mathrm{BA}$, examined in both modes, were not strong enough to be finally defined. It is possible that the resulting complexes or deposits are not sufficiently soluble or too big to be ionized with an ESI source.

The structures of luteolin-Al(III) complexes in methanol and water-methanol solutions, as well as in acid medium, were proposed by Rygula et al. (31) and Sun et al. (32). Luteolin and luteolin 7-O- $\beta$-glucuronide contain two potential chelating sites between the 5-OH and 4-keto group of chromone and the catechol group (3', 4'-diOH) in the B-ring. In the case of luteolin-Al(III) and luteolin 7-O- $\beta$-glucuronide-Al(III) coordination complexes at the stoichiometric ratio $2: 1$ two different sites from two ligand molecules are probably involved (Fig. 4). Caffeic acid presents two chelating sites in competition - the catechol group and the carboxylic function. Cornard and Lapouge showed that Al(III) preferentially coordinated the catechol group of CA and caffeate $(33,34)$. Rosmarinic acid, which is an ester of caffeic acid and 3-(3,4-dihydroxyphenyl)lactic acid, exhibits two catechol groups and both carboxylic and carboxylate functions, which can be engaged in chelation. Catechols are also known to form strong complexes with borate (36). However, the interactions of rosmarinic acid with $\mathrm{Al}(\mathrm{III})$ and BA require further research. The solutions containing flavone-BA complexes were transparent. Flavone-Al(III) complexes formation was demon- strated by the fluorescent intense yellow color of the solution and insoluble deposits on the vials bottoms, which appeared over time. That may explain the difficulties with the observation of complexes. However, it cannot be excluded that complexes in the form of an extemporary suspension are not acting, as their specific adhesiveness to vials was observed. A similar phenomenon can be observed in human mucosa.

Subsequently, the stability of the formulation was evaluated under recommended storage conditions, i.e. in a refrigerator within 7 days from the date of manufacture, because one package of the sage leaf magistral preparation in the dosage $15 \mathrm{~mL}$ twice a day is sufficient for about seven days of treatment. The study was performed at two levels for 6 preparations with identical content of polyphenols prepared with So1 and 6 preparations with different content of polyphenols prepared with So2, So3, and So7 (each in two repetitions). Changes in the content of both rosmarinic and caffeic acids and their sum are presented in Tables 6, 7, and 8, respectively. The Spearman test showed the stability of RA and SPA contents for the most analyzed magistral preparations besides Prep. So2.2.

The coefficient of variation (\%CV) for RA in the preparation of So1 did not exceed $4.35 \%$, while for other preparations it reached a maximum of $6.87 \%$ (mean value for Prep. So2-So7 was $3.67 \%$ ). For CA no more than $3.53 \%$ and $6.49 \%$ were calculated respectively (mean value of Prep. So2-So7 was $2.60 \%$ ) and for the sum of phenolic acids no more than $4.05 \%$ and $6.63 \%$ (mean value of Prep. So2-So7 was $3.49 \%$ ). The obtained results confirm the stability of the examined formulation prepared from Salviae off. fol. decoction 
in the conditions of cold storage $\left(4-6^{\circ} \mathrm{C}\right)$ within 7 days from its production.

\section{CONCLUSION}

The therapeutic activity of the examined sage leaf magistral preparation results from the presence of aluminum(III) salts, boric acid, and some polyphenols (mainly phenolic acids). In an aqueous acid medium, sage polyphenols are partially complexed by $\mathrm{Al}(\mathrm{III})$ and boric acid to soluble or non-soluble forms, and existed as precipitated sediment (especially flavonoids). On the other side, the aqueous solution of the magistral preparation, prepared according to the recommendation for direct use, is characterized by turbidity, which suggests limited solubility of the formed complexes, which was confirmed for luteolin-Al(III) and luteolin 7-O- $\beta$-glucuronide complexes by HPLCDAD and ESI-MS. The therapeutic activity should, therefore be associated with the presence of boric acid, aluminum(III) salts and non-complexed phenolic acids. The influence of flavonoid complexes is not clear, although it can be assumed that their adhesion to the mucous membrane has some influence on the overall therapeutic effect of the sage leaf magistral preparation. Examinations under recommended cool storage conditions confirmed its stability within 7 days from the date of manufacture.

\section{Acknowledgment}

This research was supported by grant SUB.D110.19.005. Technical assistance of CzaporIrzabek, H. (Laboratory of Elemental Analysis and Structural Research Faculty of Pharmacy, Wroclaw Medical University, Poland) is greatly appreciated. The authors would like to thank student Kwiesielewicz, A. (Wroclaw Medical University, Poland) and Batzella, M.F. (University of Cagliari, Italy) for laboratory help.

\section{REFERENCES}

1. Nikavar B., Abolhasani L., Izadpanah H.: Iran J. Pharm. Res. 7, 297 (2008).

2. Itani W.S., El-Banna S.H., Hassan S.B., Larsson R.L., Bazarbachi A., Gali-Mutasib H.U.: Cancer Biol. Ther. 7, 765 (2008).

3. Ayatollahi A., Shojaii A., Kobarfard F., Mohammadzadeh M., Choudhary M.: Iran J. Pharm. Res. 8, 179 (2009).

4. Smidling D., Mitic-Culafic D., Vukovic-Gacic B., Simic D., Knezevic-Vukcevic J.: Arch. Biol. Sci. Belgrade 60, 421 (2008).
5. European Union herbal monograph on Salviae officinalis L., folium. EMA/HMPC/277152/ 2015. https://www.ema.europa.eu/en/medicines/herbal/salviae-officinalis-folium/ (accessed on 19.06.2019).

6. ESCOP Monographs $2^{\text {nd }}$ Edition, Salviae officinalis L., folium, p. 452, Thieme New York 2003.

7. Fecka I., Turek S.: J. Agric. Food Chem. 55, 10908 (2007).

8. Fecka I., Turek S.: Food Chem. 108, 1039 (2008).

9. Ewald Carl Anton, Handbuch der allgemeinen und speciellen Arzneiverordnungslehre 2. Aufl., Verlag von August Hirschwald, Berlin 1892.

10. Reckzeh P.: Berliner Arzneiverordnungen: mit Einschlu $\beta$ der physikalisch-diätetischen Therapie für Studierende und Ärzte, Verlag von S. Karger, Berlin 1906.

11. Frerichs G., Arends G., Zörnig H.: Hagers Handbuch der Pharmazeutischen Praxis: für Apotheker, Arzneimittelhersteller, Drogisten, Ärzte und Medizinalbeamte. Bd. 2, 626, 2. Aufl., Verlag von Julius Springer, Berlin 1938.

12. Madaus G.: Lehrbuch der biologischen Heilmittel, Abt. 1, Heilpflanzen. Bd. 3, 2409, Georg Thieme Verlag, Leipzig 1938.

13. Podbielski J., Rostafiński M.: Polski Manuał Farmaceutyczny, p. 32, Nakładem Mag. Farm. Fr. Heroda, Warszawa 1932 (in Polish).

14. Dieterich E.: Neues Pharmaceutisches Manual, 3. Aufl., Verlag von Julius Springer, Berlin 1890.

15. Krówczyński L.: Ćwiczenia z receptury, p. 78, PZWL, Warszawa 1981 (in Polish).

16. Fink-Finowicki C.: Preparatyka galenowa: zarys farmacji stosowanej, PZWL, Warszawa 1955 (in Polish).

17. Roeske W.: Zarys fitoterapii: (Farmakologia i receptura ziół leczniczych), PZWL, Warszawa 1955 (in Polish).

18. Połomski Z.: Vademecum fitoterapii, wyd. 2, Zarząd Przemysłu Zielarskiego, Warszawa 1956 (in Polish).

19. Hano J.: Receptura: dla studentów medycyny, PZWL, Warszawa 1957 (in Polish).

20. Supniewski J.: Receptura, wyd. 3., PZWL, Warszawa 1957 (in Polish).

21. Gatty-Kostyál M.: Preparaty galenowe zasady nauki o sporządzaniu preparatów galenowych na podstawie Farmakopei Polskiej III $\mathrm{z}$ uwzględnieniem nowszych farmakopei zagranicznych, PZWL, Warszawa 1959 (in Polish). 
22. Bukowski S.: Receptura. Zarys technologii lekarstw, wyd. 2., PZWL, Warszawa 1963, wyd. 3., PZWL, Warszawa 1968 (in Polish).

23. Janicki K., Krówczyński L.: Receptura dla lekarzy i studentów, wyd. 2., Warszawa PZWL, 1999 (in Polish).

24. Frohne D.: Leksykon roślin leczniczych, wyd. 1 pol.,: MedPharm Polska, Wrocław 2010 (in Polish).

25. Farmakopea Polska XI, Vol. 1, p. 1011, Urząd Rejestracji Produktów Leczniczych, Wyrobów Medycznych i Produktów Biobójczych, Warszawa 2017 (in Polish).

26. Gokhan Z., Eulogio J.L.M., Fernández-de Córdova M.L, Babak Bahadori M., Mocan A., et al.: Ind. Crop. Prod. 111, 11 (2018).

27. Martins N., Barros L., Santos-Buelga C., Silva S., Henriques M., Ferreira I.C.F.R.: Food Chem. 167, 31 (2015).
28. Jurdt L., Geissman A.: J. Org. Chem. 21, 1395 (1956).

29. Deng H., Van Berkel G.J.: J. Mass Spectrom. 33, 1080 (1998).

30. Favaro G., Clementi C., Romani A., Vickackaite V.: J. Fluoresc. 17, 707 (2007).

31. Rygula A., Wrobel T.P., Szklarzewicz J., Baranska M.: Vib. Spectrosc. 64, 21 (2013).

32. Sun J., Wu Y., Xiao D., Lin X., Li H.: Luminescence 29, 456 (2014).

33. Cornard J.P., Lapouge C.: J. Phys. Chem. A 108, 4470 (2004).

34. Cornard J.P., Lapouge C.: J. Phys. Chem. A 110, 7159 (2006).

35. Senem S., Craig L.: Anal. Methods 6, 3858 (2014).

36. Johnson R.T., Lunte C.E.: Anal. Methods 8, 3325 (2016).

(C) 2020 by Polish Pharmaceutical Society. This is an open access article under the CC BY NC license (c) (1) (9) (http://creativecommons.org/licenses/BY/4.0/). 